\title{
PROCEDURE FOR THE ENFORCEMENT OF JUDGMENTS REGARDING MINORS IN THE CASE-LAW OF THE CONSTITUTIONAL COURT OF ROMANIA ${ }^{1}$
}

DOI: 10.47743/rdc-2018-2-0005

Marieta SAFTA ${ }^{2}$

Iulia-Elena NISTOR

\section{ABSTRACT}

This study highlights the main criticisms of unconstitutionality that have been introduced so far for the framework regulation applicable to the procedure for the enforcement of judgments regarding minors, the solutions pronounced by the Constitutional Court of Romania and the considerations that were based on, in order to contribute to the awareness of certain issues to which a legal and institutional solution must be found, in order to achieve the desire of the best interests of the child. The existence of the applications based on the legal provisions mentioned, the solutions pronounced by the courts notified, the dysfunctions found, but also bringing to public attention certain situations that revealed the need to give pre-eminence, in the settlement of these cases, the psychological side, not only counselling minors, but also their parents, are elements that may require a rethinking of the procedure for enforcing judgments regarding minors, but also of the way in which these provisions are implemented.

Keywords: minors; the best interest of the child; the enforcement of judgments

\section{Introduction. Legal framework}

The enforcement of judgments and other enforceable titles regarding minors is currently regulated by the provisions of Articles 910-914 of the Civil Procedure Code ${ }^{4}$, texts that outline the scope (Article 910), special enforcement rules (Article 911), the opposition to enforcement (Article 912), the minor's refusal (Article 913), the record of findings (Article 914).

\footnotetext{
${ }^{1}$ A topic discussed within the Conference entitled The interdisciplinary approach of litigation with minors in cases of Parental Alienation, Bucharest, 27-28 of June 2019.

${ }^{2}$ Associate Professor, PhD, Faculty of Law, "Titu Maiorescu” University of Bucharest; First Assistant-Magistrate of the Constitutional Court of Romania.

3 PhD candidate, Faculty of Law, "Titu Maiorescu” University of Bucharest.

${ }^{4}$ SECTION 2: The enforcement of judgments and other enforceable titles regarding minors, of Chapter IV of Title III of Book $5^{\text {th }}$.
} 
This procedure is applicable when the minor child has been entrusted by a judgment to one of the parents, a third party or a care institution, and the person holding the child tries to evade the enforcement of the judgment. Thus, in case of the debtor's refusal regarding the obligation of the minor entrusted with the obligation to enforce this obligation, measures of patrimonial nature may be taken provided by law for the non-performance of the obligations to be performed, respectively when the obligation is not assessable in money [Article 906 (2) of the Code of Civil Procedure], and if the debtor is of bad faith, the legislature regulated the obligation of the bailiff to notify the Prosecutor's Office attached to the enforcement court in order to start the criminal prosecution. According to Article 910 (1) of the Code of Civil Procedure, the provisions of this chapter are also applicable in the case of measures regarding minors provided in an enforceable title, such as the establishment of the minor's home, the placement, the return of the minor by the person who keeps him without being legally appointed, the exercise of the right to have personal relationships with the minor, as well as other measures provided by law.

In the specialized doctrine ${ }^{5}$ it was emphasized the specificity of the issue of the forced execution of the judgments regarding minors, respectively: the fact that the measures regarding minors in an enforceable title are not enforced directly by the use of force; the bailiff must use the means of indirectly restraining the debtor in the order provided by the legislature, so first establish the penalties for the debtor's burden by the court of enforcement and then notify the criminal investigation bodies in order to proceed to the criminal prosecution for the infringement of the judgments; the issue of the minor's refusal, the solution of which is made by the bailiff through the General Directorate of social assistance and child protection, who will notify the guardianship court in order to approve the psychological counselling of the minor; the implementation of penalties to the debtor in case the minor refuses the collaboration even after the counselling by the psychologist; if the enforcement is not carried out even after the implementation of these penalties, the creditor will be able to ask the guardianship court to fix a definitive amount for the debtor's burden.

We consider that, and in view of this specificity, the provisions that emphasize the mentioned procedure were also the subject of the unconstitutionality criticisms, although there are not a large number of cases with this subject of matter. By means of the exceptions of unconstitutionality, a delicate problem was brought before the constitutional court, with a strong psychological and sociological load, and settlements concerning the reconciliation of several factors and the competing action of several sciences, not just the law. Likewise, the European Court of Human Rights (hereinafter ECHR) has been repeatedly invested in such cases with applications based on the provisions of Article 8 of the Convention for the Protection of Human Rights and

\footnotetext{
${ }^{5}$ G. Boroi and collective, The New Code of Civil Procedure - Comments of articles, Hamangiu Publishing House, Bucharest, 2016.
} 
Fundamental Freedoms - The right to respect for private and family life, invoking the impossibility of exercising parental rights.

The existence of these applications, the settlements pronounced by the courts notified, but also the bringing to public attention of situations that have revealed the need to give pre-eminence, in settling these cases, the psychological side, counselling not only the minors, but also their parents, are elements which may require a rethinking of the procedure for enforcing judgments regarding minors, but also of how these provisions are enforced. In this key, we have to approach also the case-law of the Constitutional Court of Romania (hereinafter the $(C R$ ), since the challenges that it settled have brought many elements regarding issues of regulation or of law enforcement. However, the constitutional court cannot substitute neither the legislature nor the authorities called to enforce the law, its review being one of constitutionality, that is to say of the norms criticized in relation to the provisions of the Fundamental Law and, through their mediation, in relation to the provisions of the treaties in the matter of rights and fundamental freedoms to which Romania is a party.

From this perspective, this study has, on the one hand, an informative role, in the sense of providing an image on the main criticisms that have been brought so far to the framework regulation, the settlements pronounced by the Court and the considerations that they have substantiated, and, on the other hand, the role of contributing to the awareness of certain issues to which a legal and institutional settlement must be found, in order to achieve the desire of the best interests of the child.

\section{Criticisms of unconstitutionality formulated}

\subsection{Free access to justice and the right to a fair trial}

The most frequent of the formulated criticisms of unconstitutionality are the violation of the access to justice and the right to a fair trial, enshrined in Article 21 of the Constitution and Article 6 of the Convention for the Protection of Human Rights and Fundamental Freedoms.

Thus, it was claimed that "the criticized legal provisions are unconstitutional, as the judgment cannot be enforced as a result of the forced enforcement procedure regulated by the provisions of Articles 910-914 of the Code of Civil Procedure", proposing, consequently, a series of regulations for replacing the criticized legal provisions, after finding their unconstitutionality. It was also argued that the procedure regulated by the provisions of Articles 910-914 of the Code of Civil Procedure is unconstitutional because it limits the enforcement of judgments only to the pecuniary side $^{6}$. Other authors have invoked the fact that the legal provisions criticized are

${ }^{6}$ Decision no. 710 of 9 November 2017, published in the Official Gazette of Romania, Part I, no. 278 of 29 March 2018. 
unconstitutional because they leave it at the disposal of the debtor of bad faith the possibility of postponing or extinguishing the effects of a final or enforceable judgment, including the possibility of influencing the behaviour of the minor in the sense of rejecting the parent who has won the trial and that the creditor lacks the right gained through an enforceable title and implicitly having personal relationships with his child $^{7}$. In other cases it has been argued that the criticized regulation is unconstitutional as it establishes an absolute presumption of guilt by the debtor parent, without the effective right to a fair trial. Thus, the criticized law text would represent a civil conviction without judgment of the debtor, even when it is innocent regarding the failure of a forced execution regarding the exercise of the personal relationships with the minors. The fact that the creditor parent is presumed by law to be innocent and his guilt regarding the forced execution does not have legal relevance, which inevitably leads to the legal consequence of the presumption of the debtor's guilt and to the enforcement of penalties without existing effectively a judgment, represents a violation of the provisions of Article 6 (1) of the European Convention on Human Rights, regarding the right of any person to a fair trial. It was thus argued, in one case, that the provisions of Article 910 (3) with the enforcement of Article 906 (2) of the Code of Civil Procedure can be constitutional only insofar as the debtor parent is guilty of the minor's attitude towards the creditor parent, in the sense that he influenced the minor in the negative sense, and the alienation of the minor is due to the fault of the debtor parent, and not the fault of the creditor parent.

Examining these criticisms, the Court found ${ }^{8}$ that the procedure regulated by the provisions of Articles 910-914 included in section 2 - Enforcement of judgments and other enforceable titles regarding minors of chapter IV - Enforcement of other obligations to do or obligations not to do from the Code of Civil Procedure of Title III Direct forced execution of the Book $5^{\text {th }}-$ About the forced execution of the Code of Civil Procedure does not infringe the right to a fair trial guaranteed constitutionally and conventionally.

Thus, according to the case-law of the Court, free access to justice implies access to the procedural means by which justice is carried out. It is the exclusive competence of the legislature to establish the rules for conducting the trial before the courts of law. Moreover, it is a solution that categorically results from the provisions of Article 126 (2) of the Constitution, according to which "The jurisdiction of the courts of law and the court procedure are established by law" and of Article 129 according to which "Against judgments, interested parties and the Public Ministry may appeal, under the conditions of the law" (see, in this regard, the Decision of the Plenum of the Constitutional Court

\footnotetext{
${ }^{7}$ Decision no. 299 of 12 May 2016, published in the Official Gazette of Romania, Part I, no. 552 of 21 July 2016; Decision no. 710 of 9 November 2017, published in the Official Gazette of Romania, Part I, no. 278 of 29 March 2018.

${ }^{8}$ Ibidem.
} 
no. 1 of 8 February 1994, published in the Official Gazette of Romania, Part I, no. 69 of 16 March 1994). As a matter of principle, the provisions of Article 21 (3) of the Constitution provide for judging the trials in a fair manner and their settlement within a reasonable time, as defined by Article 6 (1) of the Convention for the Protection of Human Rights and Fundamental Freedoms. The fair trial constitutes a guarantee of the principle of legality, and the reasonable term, a guarantee that the justice ensures the achievement of the citizens' rights and freedoms, with the elimination of delays and means of a dubious nature. However, by the provisions of the Code of Articles 910-914, the legislature regulated several gradual measures in intensity, meant to compel the debtor to enforce the obligation stipulated in the enforceable title, through the court of law. By enforcing this monetary constraint, the aim is to counteract the abusive labour, tending to postpone the fulfilment of the obligations assumed by the debtor, in order to ensure speed, as an imperative requirement of forced execution. In view of these, the alleged violation of the provisions of Article 21 of the Constitution cannot be hold.

Regarding the criticism regarding the possibility of influencing the behaviour of the minor in the sense of rejecting the parent who won the trial, the Court held that the legislature provided, according to the age of the child, a psychological counselling program for a period that may not exceed 3 months, at the completion of which the psychologist appointed by the court will draw up a report. After receiving the report, the bailiff shall resume the enforcement procedure ${ }^{9}$.

At the same time, the Court emphasized that the legislature has the right to regulate the extent of the enforcement of a criminal sanction, considering the seriousness of the opposition to the execution of the debtor, as well as the protected social values, the regulation of certain specific sanctions leading to the observance of the legal norms. It is up to the competent courts of law to qualify the classification of the committed crime, taking into account the generic reference made by the legal provisions criticized to the incrimination rules depending on the specific situation ${ }^{10}$.

Moreover, as the High Court of Cassation and Justice holds in a case in this matter, the ECHR has decided that, although it is not desirable to enforce coercive measures in this sensitive area, the enforcement of sanctions should not be excluded in the case of behaviour manifestly illegal of the parent with whom the minor lives (see Judgment of 25 January 2000 in the case Ignacollo-Zenide v. Romania ${ }^{11}$, paragraph 106, and Decision of 2012 pronounced in the case lorgu Răileanu v. Romania, paragraph $\left.46^{12}\right)^{13}$.

\footnotetext{
${ }^{9}$ Ibidem.

${ }^{10}$ Decision no.847 of 13 December 2018, published in the Official Gazette of Romania, Part I, no. 177 of 5 March 2019.

11 https://hudoc.echr.coe.int/eng\#\{"itemid":["001-58448"]\}.

12 https://hudoc.echr.coe.int/eng\#\{"itemid":["001-155910"]\}.

${ }^{13}$ The High Court of Cassation and Justice - Criminal Division, Decision no. 42/A/2017 of 15 February 2017.
}

STUDIES AND ARTICLES 


\subsection{Equality in rights and equality between spouses}

It was argued in this respect that, through the criticized legal provisions, it is established the creditor's right regarding the program of personal relationships between the minor and the non-custodial parent in order to ask the court for delay penalties, in the condition that the minor still refuses to carry on personal relationships with the non-custodial parent. Thus, a presumption of guilt of the custodial parent is born in the existence of the minor's refusal to carry on relationships with the non-custodial parent, a presumption which gives rise to a discriminatory situation between the parents of the minor, being logically affected the equality of rights of the parents regarding the way in which they exercise their parental authority, while complying with the minor's rights and best and priority interests.

The Court held on these criticisms ${ }^{14}$ that, according to its case-law, equal situations must be granted equal treatment, and violations of the principle of equality and non-discrimination may exist when differentiated treatment is applied to equal cases, without objective and reasonable grounds ${ }^{15}$. The criticized legal provisions, which establish that, if the minor refuses to cooperate in order to carry out the measures of the enforceable title, even after being counselled by the psychologist, the creditor will ask the guardianship court to apply penalties, shall not affect the principle of equality of citizens before the law, as it applies to all persons under the norm hypothesis.

The Court also noted that, according to Article 906 (5) of the Code of Civil Procedure, to which the criticized legal provisions refer, the penalty may be removed or reduced, by challenging it when being enforced, if the debtor complies with the obligation stipulated in the enforceable title and proves the existence of solid grounds that justified the delay of enforcement. Therefore, it cannot be held that the debtor is in a position of inequality towards the creditor, and the establishment of a different legal treatment regarding the parent to whom the child was entrusted, compared to the other parent, is objectively and reasonably justified due to the fact that the two parents are in different legal situations, the provisions of Article 48 (1) of the Constitution regarding equality between spouses are not violated ${ }^{16}$.

\subsection{The right of the person to dispose of oneself}

Criticisms have also been formulated in the sense that, practically, by his refusal, the minor opposes the ones established in the judgment and he chooses to renounce to

\footnotetext{
${ }^{14}$ Decision no. $365 / 2018$.

${ }^{15}$ See, in this regard, Decisions no. 202 of 14 April 2005, published in the Official Gazette of Romania, Part I, no. 512 of 16 June 2005, no. 82 of 7 February 2012, published in the Official Gazette of Romania, Part I, no. 250 of 13 April 2012, or no. 141 of 7 March 2013, published in the Official Gazette of Romania, Part I, no. 182 of 2 April 2013.

16 See, in this regard, Decision no. 394 of 24 March 2011, published in the Official Gazette of Romania, Part I, no. 358 of 23 May 2011.
} 
his right to have personal relationships with the "non-resident" parent, the consequence being that the "non-resident" parent's right to have personal relationships with his child is affected, which is contrary to the provisions of Article $26(2)$ of the Constitution.

As regards the criticism that by opposing the minor to those established by the judgment, the provisions of Article 26 (2) of the Constitution are violated, the Court noted that by the phrase "the natural person has the right to dispose of oneself, if he/she does not violate the rights and freedoms of others" contained in the respective constitutional text, the constituent legislature took into account the natural person with full exercise capacity and life experience, who has the possibility to exploit this right in full knowledge of the case, a situation that is not found in the person of a minor, lacking the capacity to exercise ${ }^{17}$.

Through this interpretation of Article 26 of the Constitution, the Court did not restrain the violation of the right to dispose of oneself of the parent to whom the child was not entrusted, by the child's opposition to the personal relationships established by the judgment ${ }^{18}$.

\subsection{Protection of children and young people}

The court noted ${ }^{19}$ that, according to Article 910 (1) of the Code of Civil Procedure, the provisions regarding the enforcement of judgments regarding minors also apply in the case of measures regarding the exercise of the right to have personal relationships with the minor, and, in its case-law, the Court held that the protection of children, enshrined constitutionally in Article 49 of the Fundamental Law, is achieved by entrusting them to one parent, who exercises his/her parental rights, the other parent having the right to personal relationships with them, as well as to ensure to their growth, education, learning and professional training. Any judgment pronounced by the court in the procedure for the dissolution of the marriage will take into account the best interests of the child ${ }^{20}$.

Regarding the right to have personal relationships with the child, Article 401 (2) of the Civil Code stipulates that in case of disagreement between parents, the guardianship court decides on the ways of exercising this right, so that the enforcement of the criticized legal provisions is subsequent to the ruling by the court of law of such a decision, which is not, however, enforced, the Court notes that the criticized law text is not in contradiction with the constitutional provisions contained in Article 49 (1) on the social protection of children and young people.

\footnotetext{
${ }^{17}$ See, in this regard, Decision no. 1.287 of 8 October 8 2009, published in the Official Gazette of Romania, Part I, no. 767 of 10 November 2009.

18 Decision no. 710/2017, cited above, par. 20.

${ }^{19}$ Decision no. 365/2018, published in the Official Gazette of Romania, Part I, no. 732 of 24 August 2018.

${ }^{20}$ See, in this regard, Decision no. 1.045 of 14 of July 2009, published in the Official Gazette of Romania, Part I, no. 551 of 7 August 2009.
} 
As it has been shown in the doctrine, from the name of the section it follows that the scope of the norms that come into its composition is limited to the enforcement of the provisions regarding minors in the enforceable titles represented exclusively by the judgments (Romanian or foreign). The place and role of the minor within the forced execution of certain provisions in the judgments that concern him/her are essential because these coordinates allow the identification of the rights and the protection of the minor's best interest, including in this last phase of the civil trial. There are legal provisions in the aforementioned section that are implicitly or explicitly constituted in the rights of the minor on whom the enforcement is carried out, namely the right of the minor regarding the presence of a representative of the General Directorate of social assistance and child protection at the enforcement and, when necessary, also a psychologist; the right of the minor not to be bullied and not to be the subject of pressure for the fulfilment of the enforcement; the minor's right to refuse to leave the debtor; the minor's freedom to express his dislike towards the creditor; the minor's right to psychological counselling. Thus, the Court considered that all these provisions lead to the conclusion that the minor cannot be considered merely a simple object of the direct forced execution regulated in Title III of the Book $5^{\text {th }}$ of the Code of Civil Procedure.

The Court also held that the legislature's intention to compel the debtor, including through financial constraints, to voluntarily fulfil his/her obligations regarding the minor is clear and aims to avoid exposing or subjecting the minor to acts of enforcement that could harm him/her. The forced execution will be carried out in the presence of a representative of the General Directorate of social assistance and child protection, who will be notified of the need to appoint a representative and of the date and place where the enforcement shall take place. Paragraph (2) of Article 911 of the Code of Civil Procedure envisages the presence in performing the acts of enforcement, and not in the elaboration of their ascertaining documents, such as the conclusion or the minutes, which do not have to be signed by the representative of the Directorate. Enforcement in the absence of the representative of the directorate is sanctioned by law with the unconditional nullity of the acts of enforcements, because his/her participation appears as an extrinsic requirement to the performed act of enforcement. Instead, the psychologist's participation in the enforcement is left by the legislature to the appreciation of the bailiff, who will appoint such a specialist when the state of the minor or other concrete circumstances of the enforcement impose it. The sanction of the non-appointment or non-participation of the psychologist when imposed would be the nullity conditional on injury, within the meaning of Article 175 (1) of the Code of Civil Procedure, because the participation of the psychologist is a requirement left to the appreciation of the bailiff, being not a mandatory requirement under a legal provision ${ }^{21}$.

${ }^{21}$ Decision no. 847/2018, cited above.

CONSTITUTIONAL NEWS 


\section{Procedure for the enforcement of judgments regarding minors}

Under the title "child's refusal", Article 913 of the Code of Civil Procedure regulates two situations in which the bailiff will find the existence of an impediment to enforcement, namely: when the minor himself/herself categorically refuses to leave the debtor, respectively when the minor shows an aversion towards the creditor. In such cases, the bailiff will not put pressure on the minor, but will draw up a report of findings, which he/she shall communicate to the parties and to the representative of the General Directorate of social assistance and child protection. The latter will notify the competent court from the place where the minor is located (the guardianship and family court provided in Article 114 of the Code of Civil Procedure), in order to arrange a psychological counselling program appropriate to the child's age. The notification of the court shall be obligatory and must be done as soon as the bailiff has communicated the report of findings to the representative of the Directorate. The guardianship and family court will solve the application in the council chamber, with the summons of the parents and the person to whom the child is, if necessary, pronouncing an order that is not subject to any appeal. Since this is about taking a legal measure to protect the minor who needs psychological counselling, the procedure carried out before the court provided by Article 114 of the Code of Civil Procedure is non-contentious within the meaning of the provisions of Article 527 of the Code of Civil Procedure. The child who has reached the age of 10 shall be compulsorily heard. The court will also be able to hear the child who has not reached this age. If the court approves the counselling, it shall not last more than 3 months. At the end of the counselling, the psychologist appointed by the court shall prepare a report, which shall be communicated to the court that ordered the counselling, to the bailiff and to the General Directorate of social assistance and child protection. The report shall not be communicated to the parents or the person to whom the minor is. Article 913 (4) of the Code of Civil Procedure provides that, after receiving the report, regardless of its content, the bailiff shall resume the forced execution procedure, according to Article 911 of the Code of Civil Procedure. Resumption of enforcement is necessary to see if, following the counselling, the minor's refusal remains or not. If even this time the enforcement cannot be carried out due to the minor's refusal, the creditor shall be able to notify the guardianship court from the place where the minor is in view of applying a penalty, according to the provisions of Article 906 (2) and (4)-(6) of the Code of Civil Procedure. Although from Article 913 (5) of the Code of Civil Procedure does not result expressly, the penalty shall be applied to the debtor, and not to the minor who refused to obey the measures ordered by the judgment. The penalties established for the debtor's charge by the guardianship court will run no later than 3 months, after which, at the creditor's request, the same guardianship court will be able to turn them into a definitive fixed amount. The guardianship court shall also be able to remove or reduce the penalties established, if in the appeal to the enforcement formulated by the debtor who has fulfilled his/her obligations the existence of solid grounds that justified the delay of the enforcement is proved. Finally, even if the enforcement could not be carried out, the bailiff will draw up

STUDIES AND ARTICLES 
a report in which he will show the way of fulfilling those ordered by the enforceable title and establish the enforcement expenses, according to the provisions of Article 890 of the Code of Civil Procedure. The said report shall be an enforceable title in respect of the enforcement expenses established for the debtor ${ }^{22}$.

\subsection{Integration into the European Union}

In the case of exceptions of unconstitutionality, the provisions of Article 148 of the Constitution, regarding the Integration into the European Union, which stipulates the priority of the binding norms of the European Union (hereinafter the $E U$ ) in relation to the national law, in case there are contradictions between them.

We must specify, as a particularity of the constitutional review in relation to this constitutional text, the fact that, in itself, establishing the priority of the mandatory norms of the EU in relation to the national law belongs to the courts of law, which apply the law in the concrete disputes, since this is a problem of law enforcement, not of constitutionality.As far as the Constitutional Court is concerned, the respective European norms with binding character can be interposed in the constitutional review. In this respect, the Constitutional Court held that "the use of a European law norm within the framework of constitutional review as a norm interposed to the reference one implies, according to Article 148 (2) and (4) of the Constitution of Romania, a cumulative conditionality: on the one hand, this norm must be sufficiently clear, precise and unambiguous by itself or its meaning has been clearly, precisely and unequivocally established by the Court of Justice of the European Union, and, on the other hand, the norm must be confined to a certain level of constitutional relevance, so that its normative content supports the possible violation by the national law of the Constitution - the only direct reference norm within the constitutional review" ${ }^{23}$. To the extent that such constitutional relevance is proved, and the meaning of the European norm is unclear, the Constitutional Court may address the Court of Justice of the European Union with preliminary questions in this regard, as it has already done in another case, for example, in another matter, however, regarding the private and family life, in the Case C-673/16 Coman v. Romania.

Noting that, in the matter of enforcement of judgments regarding minors, the constitutional relevance of binding European norms in the matter has not been invoked and proved before the Constitutional Court, which can be used within the constitutional review of the provisions of the civil procedure to which we refer, the Court found that the provisions of Article 148 (2) of the Constitution have no incidence in this case ${ }^{24}$.

\footnotetext{
22 Ibidem.

${ }^{23}$ For example, Decision no. 64 of 24 February 2015, published in the Official Gazette of Romania, Part I, no. 286 of 28 April 2015, or Decision no. 668 of 18 May 2011, published in the Official Gazette of Romania, Part I, no. 487 of 8 July 2011, Decision no. 137 of 13 March 2019, published in the Official Gazette of Romania, Part I, no. 295 of 17 April 2019.

${ }^{24}$ For example, Decision no. 299/2016, cited above.
}

CONSTITUTIONAL NEWS 


\section{Conclusions}

The presentation made does not emphasize "spectacular" issues in the constitutional review framework, in the sense that the constitutional court did not allow any exception of unconstitutionality regarding the legal provisions to which we referred. Moreover, as we have shown, the number of exceptions of unconstitutionality with this subject of matter is not a relevant one in itself. However, the content of the exceptions are particularly relevant, the dysfunctions that the criticisms formulated reveal, taking into account also the particularly sensitive character of the issue that the criticized norms regulate.

What also results from this analysis is the fact that, if a certain regulation at one time is constitutional, it does not necessarily mean that it is very good or the best, hence the false idea of certain reasoning according to which a legislative solution would be in itself "good" and sufficient because it was "validated" by the Constitutional Court. The law is in a continuous transformation, under the influence of configuration factors with a high degree of complexity and dynamics. The legislature must take into account all these factors and adapt the legislation accordingly. And the enforcement of judgments regarding minors is an area that calls for such an improvement, including from the perspective of correlating civil and criminal norms, so as to ensure the effective enforcement of these judgments. From this perspective, making a brief reference to the incidence of criminal norms, in the interpretation and application of the provisions of Article 912 of the Code of Civil Procedure (according to which, if the debtor does not fulfil his/her obligation within the stipulated term, as well as when the debtor is of bad faith and hides the minor, the bailiff shall record this fact and immediately notify the prosecutor's office attached to the enforcement court in order to proceed to the criminal prosecution, for committing the offense of non-observance of the judgment), we show that the offense of non-observance of the judgments provided by Article 287 (1) letter a) of the Criminal Code includes in the objective side "the opposition to enforcement, by the opposition of resistance, towards the enforcement body". In practice, the court ${ }^{25}$ considers that only the opposition of resistance, as a form of opposition to the execution, realizes the material element of this crime, leaving out of criminal law any other actions or inactions, which, in particular, would follow or realize such an opposition to the enforcement of a judgment. The opposition of resistance can only be committed by an action, not by inaction, and it

\footnotetext{
${ }^{25}$ For example, Criminal Decision no. 167/A/2018 of the Court of Appeal O - the court analyzing the material acts of opposition to the enforcement committed by the defendant, by influencing the minor in the decision to refuse to go to the mother's domicile, notes that they do not fit the objective typicality of the offense of non-compliance with the judgments provided by Article 287 (1) letter a) of the Criminal Code, http://www.rolii.ro/hotarari/5ad5dde6e49009a81c00005e.
} 
must be explicit. In the criminal doctrine ${ }^{26}$ it was considered that the mere omission to follow up the summons and other forms of enforcement issued by the bailiff in the forced execution procedures, does not achieve the constitutive content of the offense of non-observance of the judgments, because such omissions, even if they would lead in the impossibility of enforcing a judgment, they are unfit to accomplish the material element of the offense provided by Article 287 (1) letter a) of the Criminal Code, does not interest the motive and purpose, the phrase "the opposition of resistance" includes only those actions, which materialize in explicit manifestations, unequivocal by which the blocking of the enforcement body is sought in the enforcement of the judgment, manifestations that can materialize in acts of threat, violence or personal injury committed towards the enforcement body, the attempt to suppress its life, the refusal made to allow it to carry out the forced execution act etc. At the same time, the defendant's influence on the minor in the decision to refuse to go to the mother's house, a refusal which, due to the legal provisions, generated the impossibility of enforcing the two judgments does not represent an opposition of resistance, in the sense of the ones shown in practice. However, in the case presented, the court considered that it cannot withhold the burden of the defendant, as a crime, neither the breach of the obligation established by the judgment, nor the hiding with bad faith of the minor, thus proceeding to pay it.

At the same time, the example presented, which shows the lack of an articulation of the legislation that can generate the impossibility of enforcing the judgments regarding minors, as well as the exceptions of unconstitutionality formulated, which have raised, to a large extent, issues of law or of law enforcement, demands a normative intervention, based on a multidisciplinary approach to the regulated issues. Thus, we note that the exceptions of unconstitutionality are mainly focused on the debtor's constraint for the enforcement of judgments, emphasizing the idea that he cannot be made "guilty" of the minor's eventual refusal and constrained accordingly. In other words, the centre of the concerns is also the parents, and only indirectly the minor. However, here we think that the legislature should interfere, and here we are talking about the positive obligations of the State, namely to ensure all the solutions in the plan of regulation and law enforcement, because all the subjects involved in the enforcement of such a judgment really participate in the ensuring of this enforcement, giving priority to the best interests of the child. The normative intervention must be doubled by an interpretation and application of the legal provisions that serve the above-mentioned wishes, being aware each time of the specificity of the field, including its psychological side. This is also the case-law of the European Court of Human Rights, which states, inter alia, that "42. Regarding the obligation of the State to take positive

\footnotetext{
26 M. Udroiu, Drept penal partea specială, the $5^{\text {th }}$ edition, C.H. Beck Publishing House, 2018, p. 453;
} Gh. Diaconescu, C. Duvac, Tratat de drept penal, Partea specială, C.H. Beck Publishing House, 2009, p. 601.

CONSTITUTIONAL NEWS 
measures, the Court held that Article 8 includes the right for parents to take certain steps to reunite with their children, as well as the obligation of national authorities to take such measures. This does not apply only in cases where the child is taken into the care of the State and care measures are implemented, but also in cases where parents and/or other members of the child's family arise disputes related to meetings with the children and their place of residence (see Hokkanen v. Finland, 23 September 1994, paragraph 55, series A no. 299-A). In this respect, the obligation of the State is not the same with results, but by means (see Ignaccolo-Zenide v. Romania, no. 31679/96, paragraph 94, ECHR 2000-I; Nuutinen v. Finland, no. 32842/96 , paragraph 127, ECHR 2000-VIII; Hokkanen, paragraph 55, Nistor v. Romania, no. 14565/05, paragraph 70, 109, 2 of November 2010 and Cristescu v. Romania, no. 13589/07, paragraph 57, 10 January 2012). 43. The Court has repeatedly ruled that, in matters concerning child custody, the interests of the child are of particular importance. The best interests of the child should be the primary consideration and may prevail, depending on their nature and importance, on the interests of the parents. In particular, under Article 8 of the Convention, a parent cannot require the application of measures that would affect the health and development of the child (see P.F v. Poland, no. 2210/12, paragraph 54, 16 September 2014, supplementary reference). 44 . Where the relationship with the parent seems to threaten those interests or interfere with those rights, the national authorities must accomplish a balance between them. What is decisive is whether the national authorities have taken all necessary measures to facilitate the meeting, as reasonably required in the special circumstances of each case (see Hokkanen, paragraph 58)"27. The ECHR also underlines the obligation of the authorities to take practical measures to encourage better cooperation, taking into account the best interests of the child (case Reigado Ramos v. Portugal, dated 22 December 2005).

Moreover, the ECHR case-law in this matter is consistent, so, based on Article 20 of the Constitution ${ }^{28}$, it can and should base both the necessary legislative action and the interpretation and application of the law to ensure the highest standards of protection of competing fundamental rights in the field. A recent study ${ }^{29}$ occasioned by a case that has led to fierce debates in Romania points out that "there are dozens of cases [if not even hundreds (....)] that have reached the role of the ECHR and which concern the need to enforce judgments regarding, in principle, either by the right of a parent to have access to the child who is in the second parent's care, or the right of a biological parent

\footnotetext{
27 The judgment given in the case Răileanu v. Romania, cited above, http://ier.gov.ro/wp-content/uploads/ cedo/Raileanu-împotriva-României.pdf; see also Request no. 53241/09, submitted by Gabriel Mereuță v. Romania, http://ier.gov.ro/wp-content/uploads/cedo/Cauza-Mereuta-impotriva-Romaniei.pdf.

${ }^{28}$ Which establishes the supralegislative position of the international human rights treaties to which Romania is a party and their constitutional interpretative value.

29 M. Mazilu-Babel, https://www.juridice.ro/644521/jurisprudenta-cedo-incidenta-in-speta-fetitei-din-baia-dearama-articolele-8-si-3-din-conventie-partea-i.html?fbclid=IwAR1X8vG6kXgog_dSBeMiPb6VDG5Nx8nWcamFce 5lfxoDMiU-5ic-14V_yw.
} 
to have access to the child who is in the care of maternal assistants, or the right of an adoptive parent to obtain the enforcement of favourable final judgments regarding a child who is under the guardianship of the State. What all these cases have in common is that the ECHR has reiterated the best interests of the child as the primary factor in any analysis regarding the situations in which there are definitive judgments that are not yet enforced (or not fully enforced). Also, and precisely because of the need to effectively guarantee that this best interests of the child is taken into account at national level, the ECHR has also emphasized that coercive measures aimed at the child in this sensitive area are not recommended". In the broad synthesis made, the author also underlines a series of obligations imposed by Article 8 of the ECHR in situations similar to the case he considered, respectively: the obligation not to use physical or mental constraint, the fact that the obligation to act quickly in favour of a parent's rights is not an absolute one, being limited by the best interests of the child, and implicitly by the need not to use the physical or mental constraint on the minor child, the fact that the ECHR case-law shows that it is only the possibility of applying coercive measures against the adult, and not at all against the child in these types of species. In other words, the best interests of the child must be at the centre of all these efforts because, as has been shown, in the decision making regarding child care, the best interests of the child are of paramount importance (it is not enough to show that a child could be placed in a more beneficial environment for his/her education) ${ }^{30}$.

\footnotetext{
${ }^{30}$ D.J. Harris, M. O’Boyle, E.P. Bates, C.M. Buckley (Law of the European Convention on Human Rights, Oxford University Press, August 2018, pages 548 and 549), apud M. Mazilu-Babel, www.juridice.ro.
}

CONSTITUTIONAL NEWS 